\title{
SISTEM INFORMASI MANAJEMEN STANDAR PELAYANAN MINIMUM BADAN \\ LAYANAN UMUM DAERAH DI LINGKUNGAN DINAS KOPERASI DAN UMKM \\ PEMERINTAH PROVINSI JAWA TIMUR
}

\author{
Yona Octiani Lestari \\ Fakultas Ekonomi,Universitas Islam Negeri Maulana Malik Ibrahim Malang \\ Jl. Gajayana 50 Malang Telp. 0341-551354 Faks. 0341-572533 \\ Email: yonaoctiani@yahoo.com. No Telephon: 08164292906
}

\begin{abstract}
Indonesian government has committed to provide financial aids needed by micro, small, medium, and cooperative enterprises (Kredit Usaha Mikro dan Kecil, or KUMK). The government has begun to offer funding via Kementrian Negara Koperasi dan UKM RI (Indonesian Ministry of Cooperative Enterprises and Small Enterprises), which then disseminated through other Department/Bureau and local Governments, including the Government of East Java Province.

Total amount of the grant given by August 2009 period was 476,77 billion Rupiahs, while the total installments was 364,42 billion Rupiahs. In addition, the amount of funding arrears reached 105,34 billion Rupiahs, or approximately 22,42\% of the bill plafond. The cash capital mentioned above had been absorbed by almost 26,910 KUMK in East Java. Current major institutions in channeling the funding are Bank Jawa Timur (East Java Bank) which delivers 318,15 billion Rupiahs, or around 67.73\% of total amount; and BPR Jawa Timur (East Java Rural Bank) with total 151,61 billion Rupiahs, or approximately $32.27 \%$ of total funding that had been given in the region.
\end{abstract}

Keywords: Kredit Usaha Mikro dan Kecil, funding, capital

\begin{abstract}
ABSTRAK
Pemerintah Indonesia telah berkomitmen untuk memberikan bantuan keuangan yang diperlukan oleh usaha mikro, kecil, menengah, dan koperasi (Kredit Usaha Mikro dan Kecil, atau KUMK). Pemerintah telah mulai menawarkan pendanaan melalui Kementrian Negara Koperasi Dan UKM RI ( Indonesia Departemen Koperasi Usaha Kecil dan Usaha ), yang kemudian disebarkan melalui lain Departemen/Biro dan Pemerintah Daerah, termasuk Pemerintah Provinsi Jawa Timur .

Jumlah total hibah yang diberikan oleh periode Agustus 2009 adalah 476,77 miliar rupiah, sedangkan jumlah angsuran adalah 364,42 miliar rupiah. Selain itu, jumlah tunggakan dana mencapai 105,34 miliar rupiah, atau sekitar 22,42\% dari tagihan. Modal tunai yang disebutkan di atas telah diserap oleh hampir 26.910 KUMK di Jawa Timur. Lembaga-lembaga utama saat ini dalam menyalurkan dana adalah Bank Jawa Timur (Bank Jatim) yang memberikan
\end{abstract}


318,15 miliar rupiah, atau sekitar 67,73\% dari jumlah total, dan BPR Jawa Timur (Jawa Timur Rural Bank) dengan jumlah 151,61 miliar rupiah, atau sekitar $32.27 \%$ dari total dana yang telah diberikan di wilayah tersebut.

Kata kunci: Kredit Usaha Mikro dan Kecil, Pendanaan, Modal

\section{PENDAHULUAN}

Reformasi sebagai bentuk respon positif dalam menyikapi krisis multidimensional yang memunculkan paradigma baru penyelenggaraan kehidupan bernegara terhadap norma efisiensi, partisipasi, transparansi dan akuntabilitas publik. Tuntutan dan aspirasi masyarakat tentang penyelenggaraan pemerintahan, setidaknya telah membawa beberapa hal; pertama, reformasi sistem politik untuk menuju kehidupan politik yang lebih demokratis melalui keterlibatan dan partisipasi rakyat dalam proses politik yang menyangkut kepentingan public, kedua, tuntutan good governance and clean government dalam penyelenggaraan negara yang didukung dengan prinsip dasar kepastian hukum, akuntabilitas, transparansi, keadilan, profesionalisme dan demokratis seperti yang dikumandangkan oleh World Bank, UNDP, United Nation dan beberapa lembaga international lainnya.

Peraturan Pemerintah RI No.23 Tahun 2005 tentang Pengelolaan Keuangan Badan Layanan Umum (BLU), Peraturan Menteri Dalam Negeri 61 Tahun 2007 tentang Pedoman Teknis Pengelolaan Keuangan Badan Layanan Umum Daerah dan Peraturan Gubernur Jawa Timur Nomor 29 tentang Penerapan Pola Pengelolaan BLUD Provinsi Jawa Timur sebagai salah satu pedoman yang mendasari perlunya dibentuk BLUD Pengelolaan Dana Bergulir bagi KUMKM Unit Kerja Dinas Koperasi, Pengusaha Kecil dan Menengah Propinsi Jawa Timur, diharapkan secara internal pemerintah daerah dapat meningkatkan akuntabilitas pengelolaan keuangan dan profesionalisme layanan pendanaan bergulir kepada KUMKM guna mewujudkan tata kelola pemerintahan yang baik (good governence) dan secara eksternal dapat meningkatkan kapasitas dan produktifitas usaha KUMKM. Dengan demikan KUMKM akan dapat mengembangkan skala usahanya yang dapat menyerap tenaga kerja mengurangi pengangguran dan kemiskinan di Jawa Timur. Pengelolaan keuangan dana bergulir perlu dilaksanakan sesuai tatakelola yang baik (good governance) yang mengedepankan asas-asas prudential dan penyaluran dana bergulir tersebut perlu dilakukan pembenahan secara memadai sesuai dengan peraturan keuangan negara sehingga mengurangi potensi merugikan keuangan APBD Propinsi Jawa Timur. 
Peraturan Pemerintah RI No.23 Tahun 2005 tentang Pengelolaan Keuangan Badan Layanan Umum (BLU), Peraturan Menteri Dalam Negeri 61 Tahun 2007 tentang Pedoman Teknis Pengelolaan Keuangan Badan Layanan Umum Daerah dan Peraturan Gubernur Jawa Timur Nomor 29 tentang Penerapan Pola Pengelolaan BLUD Provinsi Jawa Timur sebagai salah satu pedoman yang mendasari perlunya dibentuk BLUD Standar Pelayanan Minimal bagi KUMKM Unit Kerja Dinas Koperasi, Pengusaha Kecil dan Menengah Propinsi Jawa Timur, diharapkan secara internal pemerintah daerah dapat meningkatkan profesionalisme layanan kepada masyarakat melalui standar pelayanan minimal KUMKM dan berupaya mewujudkan tata kelola pemerintahan yang baik (good governence) dan secara eksternal dapat meningkatkan kapasitas dan produktifitas usaha KUMKM. Dengan demikan KUMKM akan dapat mengembangkan skala usahanya yang dapat menyerap tenaga kerja mengurangi pengangguran dan kemiskinan di Jawa Timur. Pengelolaan keuangan dana bergulir perlu dilaksanakan sesuai tatakelola yang baik (good governance) yang mengedepankan asas-asas prudential dan penyaluran dana bergulir tersebut perlu dilakukan pembenahan secara memadai sesuai dengan peraturan keuangan negara sehingga mengurangi potensi merugikan keuangan APBD Propinsi Jawa Timur.

\section{PEMBAHASAN}

\section{Pengertian dan Ruang Lingkup}

Untuk menjamin ketersediaan, keterjangkauan dan kualitas pelayanan umum yang diberikan BLUD, ditetapkan Standar Pelayanan Minimal (SPM) dengan mempertimbangkan kualitas layanan, pemerataan dan kesetaraan layanan serta kemudahan untuk mendapatkan layanan. SPM memuat komponen SPM, mekanisme penyaluran dana bergulir, indikator keberhasilan SPM, kondisi sumber daya, monitoring dan evaluasi. Penyaluran Dana Bergulir adalah pemberian pinjaman tambahan modal usaha untuk Koperasi serta Usaha Mikro, Kecil dan Menengah (KUMKM) yang bersumber dari APBD Propinsi Jatim.

Berdasarkan Renstra Dinas Koperasi dan UMKM tahun 2009-2014 menyebutkan beberapa pokok sasaran antara lain :

a. Penyediaan kemudahan dan pembinaan dalam memulai usaha, termasuk dalam perijinan, lokasi usaha, dan perlindungan usaha dari pengutan liar. 
b. Penyediaan skim-skim pembiayaan alternatif, seperti sistem bagi hasil (pola syari'ah) dari dana bergulir atau jaminan tokoh masyarakat setempat sebagai pengganti agunan.

c. Peningkatan akses pelaku usaha mikro terhadap permodalan dan kredit melalui pengembangan sistem perbankan alternatif yang mengadaptasi Grameen Bank System.

d. Peningkatan akses permodalan bagi pelaku usaha mikro dikaitkan percepatan sertifikasi hak atas tanah dengan memberikan pinjaman lunak untuk biaya pengurusan sertifikat.

e. Perlindungan dan peningkatan kepastian hukum bagi usaha mikro.

f. Penyediaan dukungan terhadap upaya peningkatan kapasitas kelembagaan dan kualitas layanan lembaga keuangan mikro.

g. Penyelenggaraan pelatihan budaya usaha dan kewirausahaan dan bimbingan teknis manajemen usaha.

h. Penyediaan infrastruktur dan jaringan pendukung bagi usaha mikro, serta kemitraan usaha.

i. Fasilitasi dan pemberian dukungan untuk pembentukan wadah organisasi bersama diantara usaha mikro, termasuk pedagang kaki lima, baik dalam bentuk Koperasi maupun asosiasi usaha lainnya dalam rangka meningkatkan posisi tawar dan efisiensi usaha.

j. Penyediaan dukungan pengembangan usaha mikro tradisional dan pengrajin melalui pendekatan pembinaan sentra-sentra produksi/kluster disertai dukungan penyediaan infrastruktur yang makin memadai.

k. Penyediaan dukungan dan kemudahan untuk pengembangan usaha ekonomi produktif bagi usaha skala mikro/sektor informal dalam rangka mendukung pengembangan ekonomi pedesaan, terutama didaerah tertinggal dan kantong-kantong kemiskinan

Dari sasaran pokok di atas maka program utama dalam rangka penyaluran dana bergulir adalah perkuatan permodalan bagi KUMKM di Jatim. Ruang lingkup Standar Pelayanan Minimal BLUD Dinas KUMKM Propinsi Jatim antara lain meliputi :

a. Persyaratan calon penerima dana bergulir

b. Mekanisme penyaluran dana bergulir

- Prosedur pengajuan dana bergulir perkuatan permodalan KUMKM

- Prosedur penetapan penerima pinjaman 
- Prosedur pencairan dana

- Prosedur penagihan pinjaman

c. Lembaga penyalur dan system pengembalian dana pinjaman

- Lembaga penyalur

- Sumber dana

Kerangka Konseptual penyusunan Standar Pelayanan Minimal

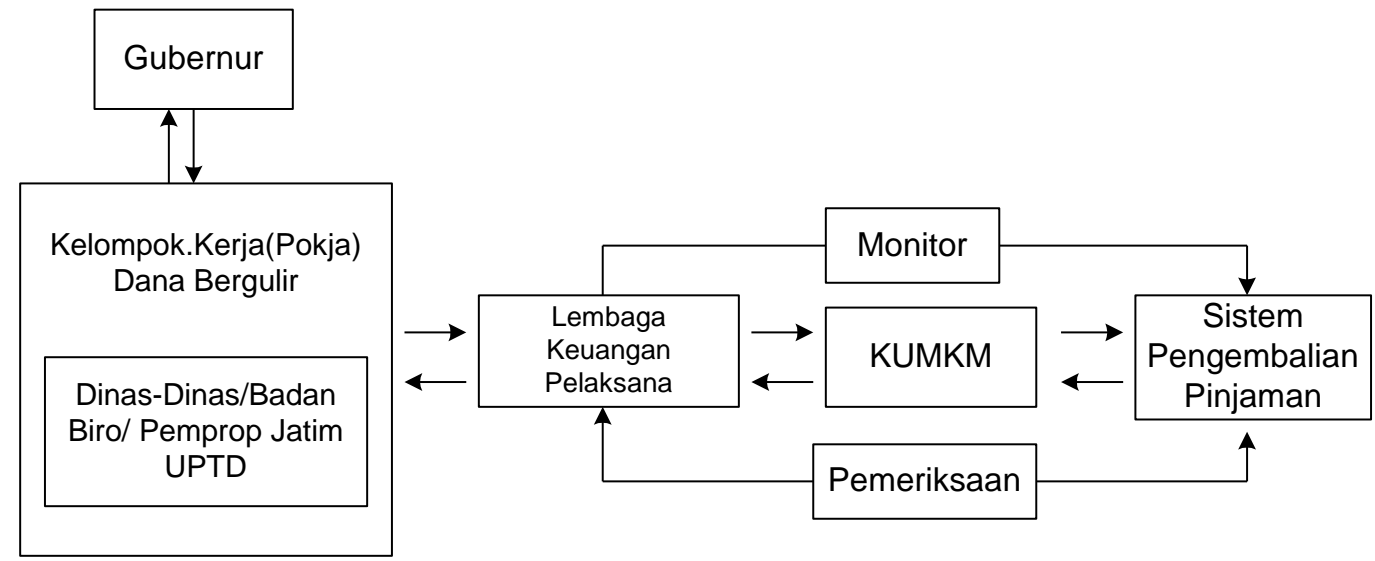

Gambar 1

Kerangka konseptual Standar Pelayanan Minimal

\section{Hak dan Kewajiban SKPD dalam Pelaksanaan Standar Pelayanan Minimal}

Struktur organisasi BLUD KKUMKM menggambarkan posisi jabatan, pembagian tugas, fungsi, tanggungjawab dan wewenang dalam organisasi. Pejabat pengelola BLUD KKUMKM terdiri dari:

1. Kepala BLUD/Kepala SKPD

2. Kepala Sub Bagian Tata Usaha

3. Kepala Seksi Teknis Operasional

4. Kepala Seksi Pembinaan dan Pengawasan 
Selain Pejabat Pengelola tersebut, perlu dibentuk Satuan Pengawas Internal (Auditor Internal) untuk mengawasi operasional BLUD dilakukan oleh Satuan Pengawas Internal (Auditor Internal). Auditor Internal berkedudukan di bawah pimpinan BLUD.

BLUD yang memiliki nilai omset tahunan (berdasarkan Laporan Operasional) atau nilai aset (berdasarkan Neraca) yang memenuhi syarat minimal, dapat dibentuk Dewan Pengawas. Syarat minimal dimaksud menurut Peraturan Menteri Keuangan Nomor:109/PMK.05/2007 tentang Dewan Pengawas Badan Layanan Umum Pasal 2, bahwa pembentukan Dewan Pengawas berlaku hanya pada BLU yang memiliki realisasi nilai omset tahunan menurut laporan realisasi anggaran tahun berakhir, minimal sebesar Rp. 15 milyar dan atau nilai aset menurut neraca, minimal sebesar Rp. 75 milyar. Jika belum mencapai realisasi anggaran yang telah ditetapkan maka fungsi dewan pengawas dalam struktur organisasi BLUD adalah sebagai berikut:

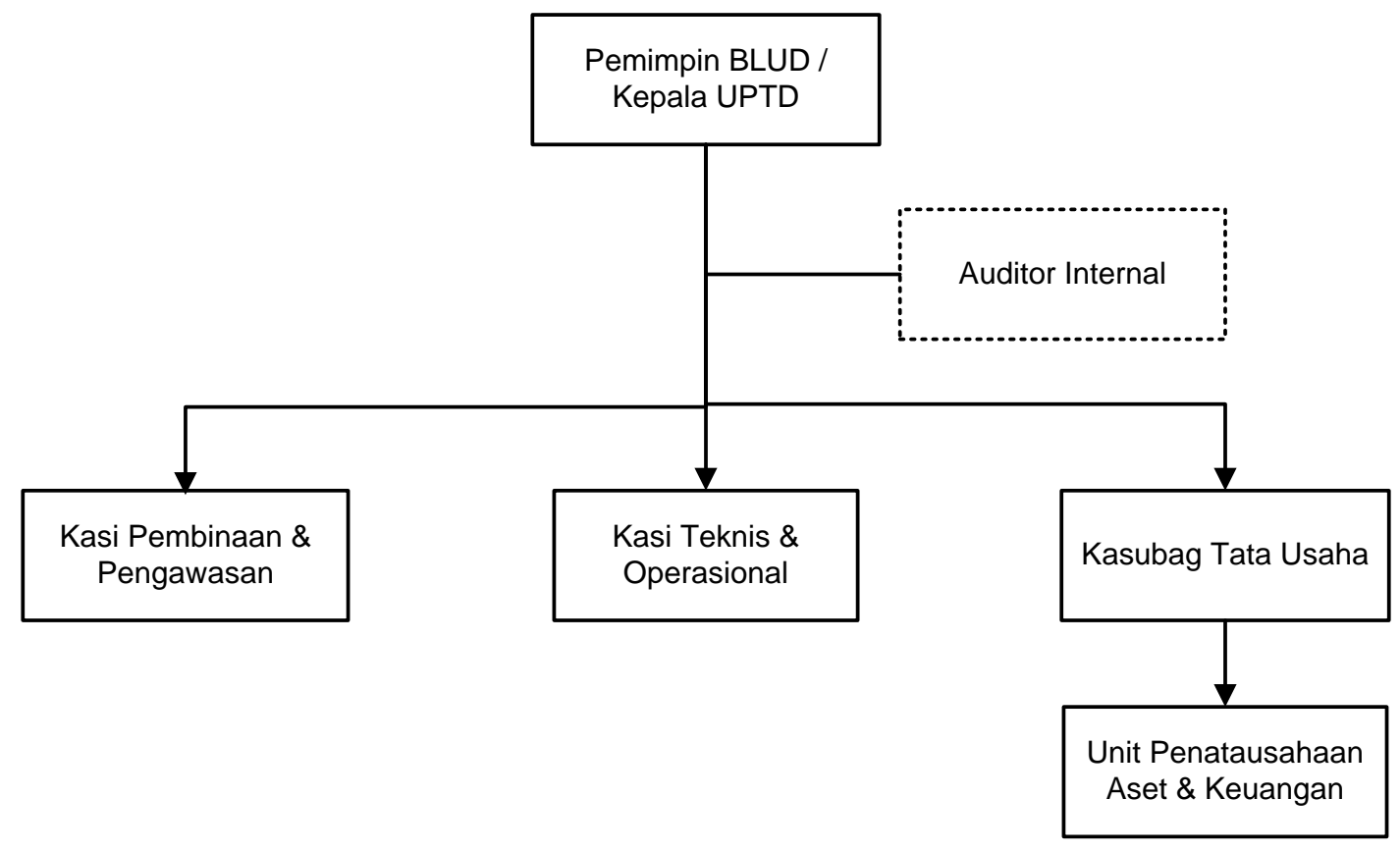

Tabel 1:

Struktur Organisasi BLUD

\section{Kewajiban Pengelola BLUD}

\section{Kepala BLUD SKPD KUMKM}

Fungsi: Penanggungjawab umum operasional dan keuangan BLUD 


\section{Uraian Tugas:}

a. Memimpin, mengarahkan, membina, mengawasi, mengendalikan dan mengevaluasi penyelenggaraan kegiatan BLUD

b. Menyusun Renstra Bisnis BLUD

c. Menyiapkan RBA

d. Menetapkan kebijakan penata usaha keuangan BLUD

e. Menetapkan kebijakan pengelolaan barang, aset tetap dan investasi

f. Menetapkan kebijakan pengelolaan SDM dan pengelompokan fungsi layanan BLUD

g. Mengusulkan calon pejabat pengelola keuangan dan pejabat teknis kepada Gubernur melalui Kepala Dinas sesuai ketentuan

h. Menetapkan pejabat lainnya sesuai kebutuhan BLUD selain pejabat yang telah ditetapkan dengan peraturan perundang-undangan

i. Mentanda tangani perjanjian pinjaman dengan KUMKM

j. Menandatangani cek giro bilyet dan surat perintah pemindah bukuan pada Bank penyalur

k. Menandatangani perjanjian kerjasama usaha dengan lembaga pihak ketiga

1. Mengelola sarana dan prasarana layanan BLUD

m. Melakukan koordinasi pembinaan dan pembiayaan usaha KUMKM dengan Dinas/Instansi Terkait baik tingkat pusat, provinsi maupun kabupaten/kota

n. Menindaklanjuti hasil evaluasi dan penilaian kinerja pengelolaan BLUD yang dilakukan oleh SPI maupun auditor eksternal

o. Menyampaikan dan mempertanggungjawabkan kinerja operasional serta keuangan BLUD kepada Gubernur melalui Kepala Dinas.

\section{Kepala Sub bag Tata Usaha}

Fungsi: Penanggungjawab administrasi dan keuangan BLUD. Uraian Tugas:

a. Melaksanakan tugas urusan kesekretariatan dan keuangan

b. Mengadministrasikan proposal pinjaman KUMKM

c. Menyusun kebijakan pengelolaan SDM

d. Menyusun kebijakan penatausahaan keuangan 
e. Menyusun kebijakan pengelolaan barang, aset tetap dan investasi

f. Mengkoordinasikan penyusunan RBA

g. Menyiapkan DPA-BLUD

h. Melakukan pengelolaan pendapatan dan biaya

i. Menyelenggarakan pengelolaan kas

j. Melakukan pengelolaan utang-piutang

k. Menyelenggarakan sistem informasi manajemen keuangan

1. Menyelenggarakan akuntansi dan penyusunan laporan keuangan

m. Memelihara sarana dan prasarana layanan BLUD

n. Menyampaikan laporan bulanan serta mempertanggungjawabkan kinerja administrasi dan keuangan BLUD kepada Pemimpin BLUD

o. Melaksanakan tugas lain yang diberikan oleh atasan.

\section{Kepala Seksi Teknis Operasional}

Fungsi: Penanggungjawab teknis operasional perkuatan modal KUMKM.

Uraian Tugas:

a. Menyusun perencanaan kegiatan teknis penyaluran dana bergulir dan kerjasama pembiayaan KUMKM dengan pihak ketiga

b. Melaksanakan kegiatan teknis pembiayaan KUMKM sesuai RBA

c. Memberikan layanan informasi tentang mekanisme penyaluran dana bergulir dan prosedur permohonan pinjaman KUMKM

d. Memberikan konsultasi teknis penyusunan proposal usaha KUMKM

e. Meneliti kelengkapan administrasi permohonan pinjaman KUMKM untuk ditetapkan sebagai KUMKM yang layak survey

f. Menyampaikan tanggapan atas kelengkapan persyaratan proposal kepada KUMKM

g. Memproses berkas permohonan pinjaman KUMKM yang layak survey untuk bahan uji petik lapangan

h. Melakukan uji petik lapangan untuk menilai kelayakan usaha KUMKM yang mengajukan pinjaman

i. Melakukan konfirmasi lapangan dan penaksiran nilai jaminan yang digunakan oleh KUMKM 
j. Memberikan rekomendasi atas hasil uji petik lapangan sebagai bahan penetapan KUMKM yang layak menerima pinjaman

k. Meneliti kelengkapan administrasi pencairan pinjaman KUMKM

1. Memproses dan mengadministrasikan pencairan pinjaman KUMKM

m. Melaksanakan diklat bagi KUMKM calon penerima dana bergulir

n. Menyimpan berkas-berkas pengajuan, persetujuan, pencairan dan jaminan pinjaman KUMKM

o. Menyusun laporan bulanan perkembangan pengelolaan dana bergulir

p. Membuat keragaman dan bagan statistik perkembangan pengelolaan dana bergulir secara periodik

q. Menyampaikan laporan bulanan dan mempertanggungjawabkan kinerja operasional penyaluran dana bergulir dan kerjasama pembiayaan KUMKM kepada Pemimpin BLUD

r. Melaksanakan tugas lain yang diberikan oleh atasan.

\section{Kepala Seksi Pembinaan dan Pengawasan}

Fungsi: Penanggungjawab teknis pembinaan dan pengawasan operasional.

Uraian Tugas:

a. Menyusun perencanaan kegiatan teknis pengawasan operasional BLUD, pengendalian internal dan penagihan piutang;

b. Melaksanakan kegiatan teknis pengawasan operasional sesuai RBA;

c. Melakukan pengendalian internal atas pengamanan harta kekayaan BLUD, akurasi sistem informasi keuangan, efisiensi dan produktivitas serta kepatuhan terhadap kebijakan penerapan praktek bisnis yang sehat;

d. Melaksanakan sosialisasi tentang peraturan/ketentuan/juknis yang di berkaitan dengan program penyaluran dana bergulir KUMKM;

e. Memonitoring pemanfaatan pinjaman dan perkembangan usaha KUMKM sesuai dengan proposal yang diajukan;

f. Memberikan teguran kepada KUMKM yang tidak menyampaikan laporan pemanfaatan pinjaman dan yang melakukan penyimpangan atas pemanfaatan pinjaman;

g. Memonitor pembayaran angsuran pinjaman yang disetorkan KUMKM melalui bank penyalur; 
h. Memberikan teguran kepada KUMKM yang tidak mengangsur pinjaman dengan tepat waktu;

i. Melakukan penagihan piutang secara langsung kepada KUMKM yang menunggak pinjaman;

j. Menginventarisir permasalahan KUMKM dalam pemanfaatan dan pengembalian pinjaman;

k. Memberikan saran dan alternatif pemecahan masalah yang dihadapi KUMKM untuk kelancaran pengembalian pinjaman;

1. Mengadministrasikan angsuran pokok dan jasa pinjaman KUMKM;

m. Memproses bukti pengembalian jaminan atas pinjaman KUMKM yang telah lunas;

n. Memperbaharui secara periodik data inventarisasi KUMKM yang memperolah dana bergulir;

o. Mengevaluasi dan membuat laporan kinerja pengembalian pinjaman KUMKM per kabupaten/kota secara periodik;

p. Menyusun upaya tindak lanjut atas hasil evaluasi dan penilaian kinerja oleh Dewan Pengawas baik keuangan maupun perspektif pelanggan, proses internal pelayanan, pembelajaran dan pertumbuhan;

q. Menyampaikan laporan bulanan dan mempertanggungjawabkan kinerja pengawasan operasional kepada Pemimpin BLUD;

r. Melakukan tugas lain yang diberikan oleh atasan.

\section{Auditor Internal}

Fungsi: Mendukung terciptanya sistem pengendalian internal yang memadai di lingkungan BLUD SKPD KKUMKM.

Uraian Tugas:

a. Membantu menciptakan sistem pengendalian internal yang efektif di lingkungan BLUD SKPD KKUMKM;

b. Membantu mengawasi kepatuhan pelaksanaan sistem pengendalian internal sesuai dengan peraturan perundang-undangan yang berlaku; 
c. Melakukan penilaian terhadap sistem pengendalian internal yang berlaku serta pelaksanaannya di semua kegiatan, fungsi dan program BLUD SKPD KKUMKM terkait dengan :

$\checkmark$ Melaksanakan audit penyelenggaraan program dan kegiatan sesuai dengan standar pelayanan minimal yang telah ditetapkan

$\checkmark$ Melaksanakan audit keuangan dan ketaatan pada peraturan perundang-undangan yang berlaku

$\checkmark$ Melaksanakan penilaian daya guna dan kehematan dalam penggunaan sarana, prasarana, dan sistem informasi dalam pelaksanaan program dan kegiatan BLUD SKPD KKUMKM

$\checkmark$ Melaksanakan penilaian atas pendayagunaan dan pengembangan sumber daya manusia BLUD SKPD KKUMKM

\section{Hak Pengelola BLUD}

Salah satu bentuk penghargaan dalam penilaian kinerja adalah pemberian renumerasi. Sesuai dengan Permendagri No. 61 Tahun 2007 tentang Pedoman Teknis Pengelolaan Keuangan Badan Layanan Umum Daerah (BLUD)

1. Pejabat pengelola BLUD, dewan pengawas, sekretaris dewan pengawas dan pegawai BLUD dapat diberikan remunerasi sesuai dengan tingkat tanggungjawab dan tuntutan profesionalisme yang diperlukan.

2. Remunerasi merupakan imbalan kerja yang dapat berupa gaji, tunjangan tetap, honorarium, insentif, bonus atas prestasi, pesangon, dan/atau pensiun.

3. Remunerasi bagi dewan pengawas dan sekretaris dewan pengawas diberikan dalam bentuk honorarium.

4. Remunerasi untuk BLUD-SKPD ditetapkan oleh kepala daerah berdasarkan usulan yang disampaikan oleh pemimpin BLUD-SKPD melalui sekretaris daerah.

5. Remunerasi untuk BLUD-Unit Kerja ditetapkan oleh kepala daerah berdasarkan usulan pemimpin BLUD-Unit Kerja melalui kepala SKPD.

6. Penetapan remunerasi pemimpin BLUD, mempertimbangkan faktor-faktor yang berdasarkan: 
a. Ukuran (size) dan jumlah aset yang dikelola BLUD, tingkat pelayanan serta produktivitas;

b. Pertimbangan persamaannya dengan industri pelayanan sejenis;

c. Kemampuan pendapatan BLUD bersangkutan; dan

d. Kinerja operasional BLUD yang ditetapkan oleh kepala daerah dengan mempertimbangkan antara lain indikator keuangan, pelayanan, mutu dan manfaat bagi masyarakat.

7. Remunerasi pejabat keuangan dan pejabat teknis ditetapkan paling banyak sebesar $90 \%$ (sembilan puluh persen) dari remunerasi pemimpin BLUD.

\section{Penilaian :}

1. Remunerasi bagi pejabat pengelola dan pegawai BLUD sebagaimana dimaksud, dapat dihitung berdasarkan indikator penilaian:
a. Pengalaman dan masa kerja (basic index)-,
b. Keterampilan ilmu pengetahuan dan perilaku (competency index)\}
c. Resiko kerja (risk index);
d. Tingkat kegawatdaruratan (emergency index);
e. Jabatan yang disandang (position index); dan
f. Hasil/capaian kinerja (performance index).

2. Bagi pejabat pengelola dan pegawai BLUD yang berstatus PNS, gaji pokok dan tunjangan mengikuti peraturan perundangan-undangan tentang gaji dan tunjangan PNS serta dapat diberikan tambahan penghasilan sesuai remunerasi yang ditetapkan oleh kepala daerah.

\section{Pelayanan Teknis dan Penunjang Teknis}

\section{Bentuk Struktur Organisasi}

Struktur organisasi BLUD KUMKM menggambarkan posisi jabatan, pembagian tugas, fungsi, tanggungjawab dan wewenang dalam organisasi. Pejabat pengelola BLUD KUMKM terdiri dari:

$\checkmark \quad$ Kepala BLUD/Kepala UPTD

$\checkmark \quad$ Kepala Sub Bagian Tata Usaha 
$\checkmark \quad$ Kepala Seksi Teknis Operasional

$\checkmark \quad$ Kepala Seksi Pembinaan dan Pengawasan

Selain Pejabat Pengelola tersebut, perlu dibentuk Satuan Pengawas Internal (Auditor Internal) untuk mengawasi operasional BLUD dilakukan oleh Satuan Pengawas Internal (Auditor Internal). Auditor Internal berkedudukan di bawah pimpinan BLUD.

BLUD yang memiliki nilai omset tahunan (berdasarkan Laporan Operasional) atau nilai aset (berdasarkan Neraca) yang memenuhi syarat minimal, dapat dibentuk Dewan Pengawas. Syarat minimal dimaksud menurut Peraturan Menteri Keuangan Nomor:109/PMK.05/2007 tentang Dewan Pengawas Badan Layanan Umum Pasal 2, bahwa pembentukan Dewan Pengawas berlaku hanya pada BLU yang memiliki realisasi nilai omset tahunan menurut laporan realisasi anggaran tahun berakhir, minimal sebesar Rp. 15 milyar dan atau nilai aset menurut neraca, minimal sebesar Rp. 75 milyar. Jika belum mencapai realisasi anggaran yang telah ditetapkan maka fungsi dewan pengawas dalam struktur organisasi BLUD adalah sebagai berikut:

Gambar 2. Bagan Struktur Organisasi BLUD KUMKM Jatim 


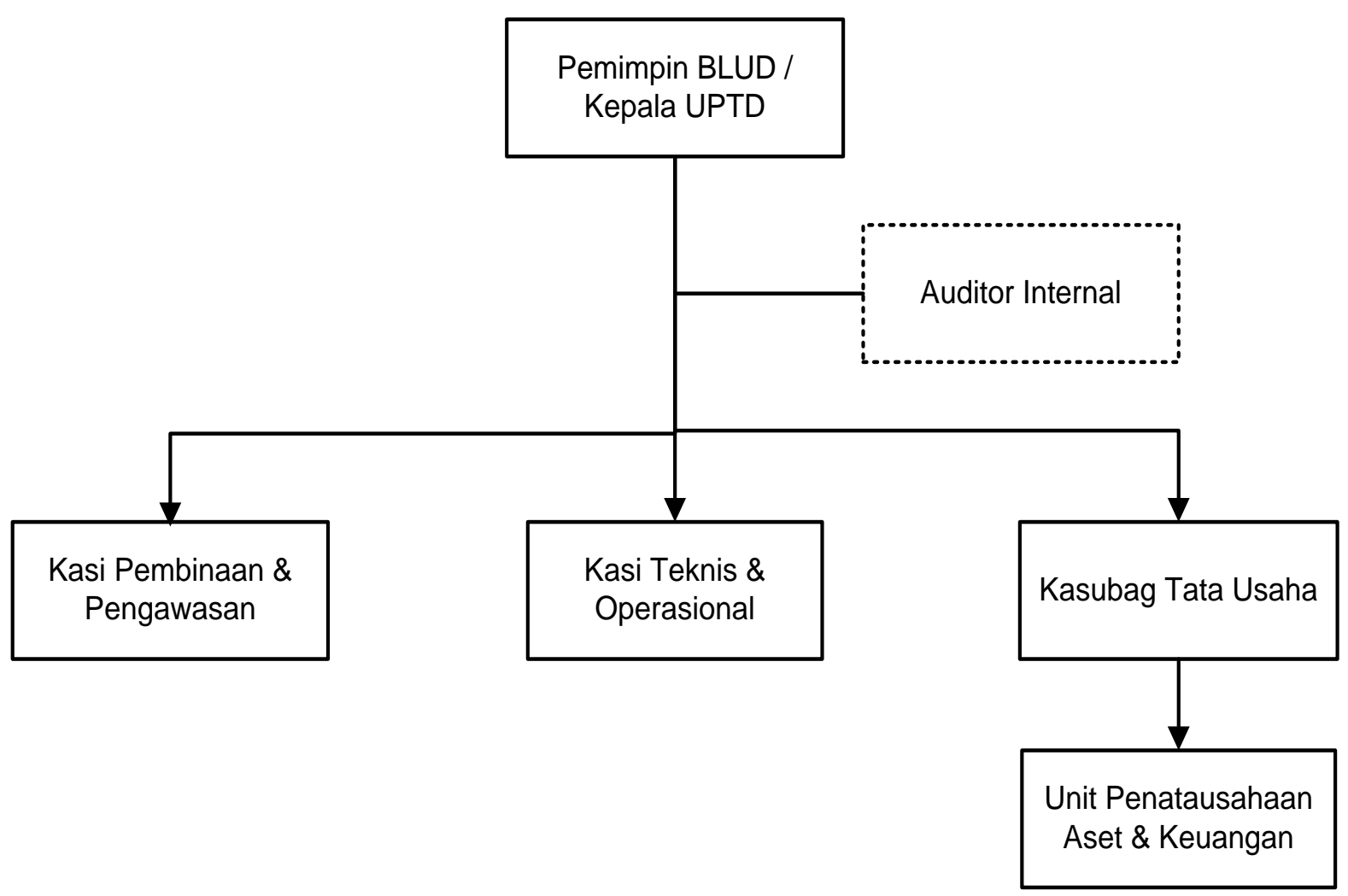




\section{Uraian Tugas Pengelola BLUD \\ Kepala BLUD UPTD KUMKM}

Fungsi: Penanggungjawab umum operasional dan keuangan BLUD

Uraian Tugas:

$\checkmark \quad$ Memimpin, mengarahkan, membina, mengawasi, mengendalikan dan mengevaluasi penyelenggaraan kegiatan BLUD

$\checkmark \quad$ Menyusun Renstra Bisnis BLUD

$\checkmark \quad$ Menyiapkan RBA

$\checkmark \quad$ Menetapkan kebijakan penatausahaan keuangan BLUD

$\checkmark \quad$ Menetapkan kebijakan pengelolaan barang, aset tetap dan investasi

$\checkmark \quad$ Menetapkan kebijakan pengelolaan SDM dan pengelompokan fungsi layanan BLUD

$\checkmark \quad$ Mengusulkan calon pejabat pengelola keuangan dan pejabat teknis kepada Gubernur melalui Kepala Dinas sesuai ketentuan

$\checkmark \quad$ Menetapkan pejabat lainnya sesuai kebutuhan BLUD selain pejabat yang telah ditetapkan dengan peraturan perundang-undangan

$\checkmark \quad$ Manandatangani perjanjian pinjaman dengan KUMKM

$\checkmark \quad$ Menandatangani cek giro bilyet dan surat perintah pemindahbukuan pada Bank penyalur;

$\checkmark \quad$ Menandatangani perjanjian kerjasama usaha dengan lembaga pihak ketiga

- Mengelola sarana dan prasarana layanan BLUD

- Melakukan koordinasi pembinaan dan pembiayaan usaha KUMKM dengan Dinas/Instansi Terkait baik tingkat pusat, provinsi maupun kabupaten/kota

- Menindaklanjuti hasil evaluasi dan penilaian kinerja pengelolaan BLUD yang dilakukan oleh Satuan Pengawas Internal (auditor internal) maupun auditor eksternal

- Menyampaikan dan mempertanggungjawabkan kinerja operasional serta keuangan BLUD kepada Gubernur melalui Kepala Dinas.

\section{Kepala Subbag Tata Usaha}

Fungsi: Penanggungjawab administrasi dan keuangan BLUD.

Uraian Tugas:

$\checkmark \quad$ Melaksanakan tugas urusan kesekretariatan dan keuangan 
$\checkmark \quad$ Mengadministrasikan proposal pinjaman KUMKM

$\checkmark \quad$ Menyusun kebijakan pengelolaan SDM

$\checkmark \quad$ Menyusun kebijakan penatausahaan keuangan

$\checkmark \quad$ Menyusun kebijakan pengelolaan barang, aset tetap dan investasi

$\checkmark \quad$ Mengkoordinasikan penyusunan RBA

$\checkmark \quad$ Menyiapkan DPA-BLUD

$\checkmark \quad$ Melakukan pengelolaan pendapatan dan biaya

$\checkmark \quad$ Menyelenggarakan pengelolaan kas

$\checkmark \quad$ Melakukan pengelolaan utang-piutang

$\checkmark \quad$ Menyelenggarakan sistem informasi manajemen keuangan

$\checkmark \quad$ Menyelenggarakan akuntansi dan penyusunan laporan keuangan

$\checkmark \quad$ Memelihara sarana dan prasarana layanan BLUD

$\checkmark \quad$ Menyampaikan laporan bulanan serta mempertanggungjawabkan kinerja administrasi dan keuangan BLUD kepada Pemimpin BLUD

$\checkmark \quad$ Melaksanakan tugas lain yang diberikan oleh atasan.

\section{Kepala Seksi Teknis Operasional}

Fungsi: Penanggungjawab teknis operasional perkuatan modal KUMKM.

Uraian Tugas:

$\checkmark \quad$ Menyusun perencanaan kegiatan teknis penyaluran dana bergulir dan kerjasama pembiayaan KUMKM dengan pihak ketiga

$\checkmark \quad$ Melaksanakan kegiatan teknis pembiayaan KUMKM sesuai RBA

$\checkmark \quad$ Memberikan layanan informasi tentang mekanisme penyaluran dana bergulir dan prosedur permohonan pinjaman KUMKM

$\checkmark \quad$ Memberikan konsultasi teknis penyusunan proposal usaha KUMKM

$\checkmark \quad$ Meneliti kelengkapan administrasi permohonan pinjaman KUMKM untuk ditetapkan sebagai KUMKM yang layak survey

$\checkmark \quad$ Menyampaikan tanggapan atas kelengkapan persyaratan proposal kepada KUMKM

$\checkmark \quad$ Memproses berkas permohonan pinjaman KUMKM yang layak survey untuk bahan uji petik lapangan 
$\checkmark \quad$ Melakukan uji petik lapangan untuk menilai kelayakan usaha KUMKM yang mengajukan pinjaman

$\checkmark \quad$ Melakukan konfirmasi lapangan dan penaksiran nilai jaminan yang digunakan oleh KUMKM

$\checkmark \quad$ Memberikan rekomendasi atas hasil uji petik lapangan sebagai bahan penetapan KUMKM yang layak menerima pinjaman

$\checkmark \quad$ Meneliti kelengkapan administrasi pencairan pinjaman KUMKM

$\checkmark \quad$ Memproses dan mengadministrasikan pencairan pinjaman KUMKM

$\checkmark \quad$ Melaksanakan diklat bagi KUMKM calon penerima dana bergulir

$\checkmark \quad$ Menyimpan berkas-berkas pengajuan, persetujuan, pencairan dan jaminan pinjaman KUMKM

$\checkmark \quad$ Menyusun laporan bulanan perkembangan pengelolaan dana bergulir;

$\checkmark \quad$ Membuat keragaman dan bagan statistik perkembangan pengelolaan dana bergulir secara periode

$\checkmark \quad$ Menyampaikan laporan bulanan dan mempertanggungjawabkan kinerja operasional penyaluran dana bergulir dan kerjasama pembiayaan KUMKM kepada Pemimpin BLUD

$\checkmark \quad$ Melaksanakan tugas lain yang diberikan oleh atasan.

\section{Kepala Seksi Pembinaan dan Pengawasan}

Fungsi: Penanggungjawab teknis pembinaan dan pengawasan operasional.

\section{Uraian Tugas:}

$\checkmark \quad$ Menyusun perencanaan kegiatan teknis pengawasan operasional BLUD, pengendalian internal dan penagihan piutang

$\checkmark \quad$ Melaksanakan kegiatan teknis pengawasan operasional sesuai RBA;

$\checkmark \quad$ Melakukan pengendalian internal atas pengamanan harta kekayaan BLUD, akurasi sistem informasi keuangan, efisiensi dan produktivitas serta kepatuhan terhadap kebijakan penerapan praktek bisnis yang sehat

$\checkmark \quad$ Melaksanakan sosialisasi tentang peraturan/ketentuan/juknis yang diberkaitan dengan program penyaluran dana bergulir KUMKM 
$\checkmark \quad$ Memonitoring pemanfaatan pinjaman dan perkembangan usaha KUMKM sesuai dengan proposal yang diajukan

$\checkmark \quad$ Memberikan teguran kepada KUMKM yang tidak menyampaikan laporan pemanfaatan pinjaman dan yang melakukan penyimpangan atas pemanfaatan pinjaman

$\checkmark \quad$ Memonitor pembayaran angsuran pinjaman yang disetorkan KUMKM melalui bank penyalur

$\checkmark \quad$ Memberikan teguran kepada KUMKM yang tidak mengangsur pinjaman dengan tepat waktu

$\checkmark \quad$ Melakukan penagihan piutang secara langsung kepada KUMKM yang menunggak pinjaman

$\checkmark \quad$ Menginventarisir permasalahan KUMKM dalam pemanfaatan dan pengembalian pinjaman

$\checkmark \quad$ Memberikan saran dan alternatif pemecahan masalah yang dihadapi KUMKM untuk kelancaran pengembalian pinjaman

$\checkmark \quad$ Mengadministrasikan angsuran pokok dan jasa pinjaman KUMKM

$\checkmark \quad$ Memproses bukti pengembalian jaminan atas pinjaman KUMKM yang telah lunas

$\checkmark \quad$ Memperbaharui secara periodik data inventarisasi KUMKM yang memperolah dana bergulir

$\checkmark \quad$ Mengevaluasi dan membuat laporan kinerja pengembalian pinjaman KUMKM per kabupaten/kota secara periodik

$\checkmark \quad$ Menyusun upaya tindak lanjut atas hasil evaluasi dan penilaian kinerja oleh Dewan Pengawas baik keuangan maupun perspektif pelanggan, proses internal pelayanan, pembelajaran dan pertumbuhan

$\checkmark \quad$ Menyampaikan laporan bulanan dan mempertanggungjawabkan kinerja pengawasan operasional kepada Pemimpin BLUD

$\checkmark \quad$ Melakukan tugas lain yang diberikan oleh atasan.

\section{Auditor Internal}

Fungsi dari auditor internal adalah mendukung terciptanya sistem pengendalian internal yang memadai di lingkungan BLUD SKPD KUMKM. 


\section{Uraian Tugas:}

$\checkmark \quad$ Membantu menciptakan sistem pengendalian internal yang efektif di lingkungan BLUD SKPD KUMKM;

$\checkmark \quad$ Membantu mengawasi kepatuhan pelaksanaan sistem pengendalian internal sesuai dengan peraturan perundang-undangan yang berlaku;

$\checkmark \quad$ Melakukan penilaian terhadap sistem pengendalian internal yang berlaku serta pelaksanaannya di semua kegiatan, fungsi dan program BLUD SKPD KUMKM terkait dengan:

a. Melaksanakan audit penyelenggaraan program dan kegiatan sesuai dengan standar pelayanan minimal yang telah ditetapkan

b. Melaksanakan audit keuangan dan ketaatan pada peraturan perundang-undangan yang berlaku

c. Melaksanakan penilaian daya guna dan kehematan dalam penggunaan sarana, prasarana, dan sistem informasi dalam pelaksanaan program dan kegiatan BLUD SKPD KUMKM

d. Melaksanakan penilaian atas pendayagunaan dan pengembangan sumber daya manusia BLUD SKPD KUMKM

\section{Pelayanan Penunjang Non Teknis}

Untuk menunjang kelancaran pelaksanaan program penyaluran dana bergulir oleh SKPDD PPKUMKM minimum sarana dan prasarana tersedia sebagai berikut:

\section{Bangunan Kantor}

Bangunan kantor yang memadai dengan tersedianya antara lain:
a. Ruangan Manajemen SKPDD PP-KUMKM
b. Ruangan Administrasi
c. Ruangan Rapat
d. Ruangan Penunjang lainnya

\section{Kendaraan Pimpinan}

Untuk menunjang kegiatan SKPDD PP-KUMKM dalam penyaluran Dana Bergulir kepada KUMKM, perlu disiapkan kendaraan pimpinan berupa roda empat 1 unit. 


\section{Kendaraan Operasional}

Untuk menunjang kegiatan SKPDD PP-KUMKM dalam penyaluran Dana Bergulir kepada KUMKM, perlu disiapkan kendaraan operasional berupa roda empat minimum 1 (satu) unit dan roda 2 (dua) minimum dua unit.

\section{Peralatan dan Mesin}

Hardware dan software komputer berbasis web yang memenuhi spesifikasi memadai, perangkat alat komunikasi seperti telepon, faksimili, serta perangkat penunjang lainnya seperti mesin foto copy, mesin ketik manual, kalkulator berdasarkan kebutuhan yang telah direncanakan. Sarana dan Prasarana lainnya sesuai dengan kebutuhan yang telah direncanakan.

\section{KESIMPULAN}

Kesimpulan yang diperoleh dari penelitian ini sebagai berikut :

1. Dalam rangka penyediaan dana bagi usaha mikro, kecil menengah dan koperasi serta sektor lainnya pemerintah sejak tahun 2000 mulai menyalurkan dana bergulir melalui Kementerian Negara Koperasi dan UKM RI, yang kemudian tersebar di beberapa Kementerian Negara/Lembaga dan diikuti oleh Pemerintah Daerah termasuk Pemerintah Provinsi Jawa Timur.

2. Jumlah dana bergulir yang telah disalurkan sampai dengan periode Bulan Agustus 2009 mencapai plafon sebesar Rp 469,77 milyar dengan total angsuran sebesar Rp 364,42 milyar. Sementara jumlah tunggakan mencapai Rp 105,34 milyar atau sekitar 22,42\% dari plafon. Dana tersebut diatas diserap oleh sekitar 26.910 KUMK tersebar di seluruh Jawa Timur. Lembaga penyalur untuk dana bergulir saat ini terbesar dilakukan oleh Bank Jawa Timur dengan nilai penyaluran sebesar Rp 318, 15 milyar atau sekitar 67,73\%, sedangkan yang melalui BPR Jawa Timur sebesar Rp 151,61 milyar atau sekitar 32,27\%.

3. Ruang lingkup Standar Pelayanan Minimal BLUD Dinas KUMKM Propinsi Jatim untuk tahun lima tahun kedepan masih pada perkuatan permodalan KUMKM di Jawa Timur, dengan focus pelayanan antara lain :

\section{Bidang Perkoperasian:}

a. Penyelenggaraan perizinan satu atap kepada koperasi dan UKM 
b. Penilai Koperasi terbaik ditingkat daerah.

c. Pengawasan pelaksanaan kerjasama antar koperasi dengan Usaha besar dan usaha menengah.

d. Penetapan bidang kegiatan ekonomi yang hanya boleh diusahakan oleh koperasi

e. Penetapan bidang kegiatan ekonomi disuatu wilayah yang telah berhasil diusahakan oleh Koperasi untuk tidak diusahkan oleh badan usaha lainya.

f. Penyuluhan dan bantuan konsultasi guna memecahkan permasalahan yang dihadapi oleh koperasi dengan memprhatikan Anggaran dasar koperasi .

g. Pemrosesan pengesahan akta pendirian dan perubahan anggaran dasar koperasi. Penempatan Modal Daerah/Keuangan Daerah pada modal penyertaan koperasi

h. Penilaian dan menyeleksi koperasi yang akan mendapatkan bantuan dan fasilitas dari Pemerintah.

i. Penilaian dan menyeleksi koperasi yang akan mendapatkan bantuan dan fasilitas dari Pemerintah

\section{Bidang Usaha Kecil dan Menengah:}

a. Penetapan tatacara, persyaratan dan jenis perizinan dengan mengupayakan terwujudnya system pelayanan satu atap.

b. Penetapan peruntukan tempat usaha yang meliputi pemberian lokasi di pasar, ruang pertokohan, lokasi sentra industri, lokasi pertanian rakyat, lokasi pertambangan rakyat, dan lokasi yang wajar bagi pedagang kai lima, serta lokasi lainya

c. Pencadangan bidang dan jenis kegiatan usaha yang memiliki kekhususan peroses, bersifat padat karya, serta mempunyai nilai seni budaya yang bersifat khusus dan turun temurun

d. Penetapan pengunaan produk yang dihasilkan Usaha Kecil melalui pengadaan Pemerintah Daerah

e. Pengaturan pengadaan barang atas jasa dan pemborongan kerja Pemerintah

\section{DAFTAR PUSTAKA}

Bastian, I. 2006. Akuntansi Sektor Publik: Suatu Pengantar. Penerbit Erlangga. Jakarta 
Komite Nasional Kebijakan Governance, 2006. Pedoman Umum Good Corporate Governance Indonesia.

Peraturan Daerah No. 4 Tahun 2007 tentang Pemberdayaan Koperasi, Usaha Mikro, Kecil dan Menengah (KUMKM)

Peraturan Direksi Lembaga Pengelola Dana Bergulir Koperasi dan Usaha Mikro, Kecil dan Menengah Nomor: 011/PER/LPDB/2011 tentang Petunjuk Teknis Pemberian Pinjaman Kepada Usaha Kecil dan Menengah Direksi Lembaga Pengelola Dana Bergulir Koperasi dan Usaha Mikro, Kecil dan Menengah

Peraturan Direksi Lembaga Pengelola Dana Bergulir Koperasi dan Usaha Mikro, Kecil dan Menengah Nomor: 36/PER/LPDB/2010 Tentang Petunjuk Teknis Pemberian Pinjaman/Pembiayaan Kepada Koperasi Direksi Lembaga Pengelola Dana Bergulir Koperasi Dan Usaha Mikro, Kecil Dan Menengah

Peraturan Gubernur Jawa Timur Nomor : 29 Tahun 2008 tentang Pedoman Penerapan Pola Pengelolaan Keuangan Badan Layanan Umum Daerah (BLUD) Provinsi Jawa Timur

Peraturan Gubernur Jawa Timur Nomor : 38 Tahun 2009 tentang Rencana Pembangunan Jangka Menengah Daerah (RPJMD) Tahun 2009 s.d 2014 Pemerintah Provinsi Jawa Timur.

Peraturan Menteri Dalam Negeri Nomor : 13 Tahun 2006 tentang Pedoman Pengelolaan Keuangan Daerah

Peraturan Menteri Dalam Negeri Nomor : 61 Tahun 2007 tentang Pedoman Teknis Pengelolaan Keuangan Badan Layanan Umu Daerah (BLU)

Peraturan Menteri Keuangan Nomor : 76/PMK.05/2008 tentang Pedoman Akuntansi dan Pelaporan Keuangan Badan Layanan Umum (BLU)

Peraturan Menteri Keuangan Nomor : 99/PMK.05/2008 tentang Pedoman Pengelolaan Dana Bergulir pada Kementerian/Lembaga

Peraturan Pemerintah Nomor : 23 Tahun 2005 tentang Pengelolaan Keuangan Badan Layanan Umum (BLU)

Peraturan Pemerintah Nomor : 24 Tahun 2005 tentang Standar Akuntansi Pemerintahan

Peraturan Pemerintah Nomor : 58 Tahun 2005 tentang Pengelolaan Keuangan Daerah

Peraturan Presiden Nomor :5 Tahun 2010 tentang Rencana Pembangunan Jangka Menengah Nasional Tahun 2010 - 2014.

Romney, M.B dan P.J. Steinbart. 2006. Accounting Information System. Penerbit Salemba Empat. Jakarta. 
Undang-undang No. 25 Tahun 2004 tentang Sistem Perencanaan Pembangunan Nasional

Undang-undang No. 25 Tahun 2004 tentang Sistem Perencanaan Pembangunan Nasional

Undang-undang Nomor : 1 Tahun 2004 tentang Perbendaharaan Negara

Undang-undang Nomor : 15 Tahun 2004 tentang Pemeriksaan Pengelolaan dan Tanggung Jawab Keuangan Negara

Undang-undang Nomor : 17 tahun 2003 tentang Keuangan Negara

Undang-undang Nomor : 20 Tahun 2008 tentang Usaha Mikro, Kecil dan Menengah

Undang-undang Nomor : 25 Tahun 1992 tentang Perkoperasian

Van Greuning, H. dan S. B. Bratanovic. 2011. Analisis Risiko Perbankan: Kerangka Kerja untuk Menaksir Tata Kelola Perusahaan dan Manajemen Risiko. Edisi Ketiga. Penerbit Salemba Empat. Jakarta.

Widjajanto, N. 2001. Sistem Informasi Akuntansi. Penerbit Erlangga. Jakarta. 